\title{
PENGARUH MODEL PEMBELAJARAN BERBASIS MASALAH BERBANTUAN MEDIA ANIMASI TERHADAP KEMAMPUAN BERPIKIR KRITIS DAN HASIL BELAJAR FISIKA SISWA SMAN 5 MATARAM TAHUN AJARAN 2016/2017
}

\author{
Haris Munandar*, Sutrio, Muhammad Taufik \\ Program Studi Pendidikan Fisika, Universitas Mataram \\ *Email: hmunandar33@gmail.com
}

\begin{abstract}
The aim of this research is to know the impact of the applying of problem-based learning model (PBLM) with animation toward the critical thinking skill and result of learning physics of student of SMAN 5 Mataram academic year 2016/2017. This research is belong to quasi experimental with nonequivalent control group design. The population is all student of XI MIPA at SMAN 5 Mataram, while the sample are class XI MIPA 4 as the experimental class, and the XI MIPA 6 as control class. The sample taken by the random sampling. The collect of data is done by give the test, 20 multiple choice to knowing the result of learning phyisics and 5 essays to knowing the student's critical thinking skill. The collected data has been analyzed by using the $t^{\prime}$-test. The result of this research shows that (1) there is an impact of the applying of PBLM with animation toward the student's critical thinking skill that includes the ability in: (a) focusing the question, (b) analyzing the argument/identificating the reason, $(c)$ inducing and considering the result of induction, $(d)$ evaluating the result of consideration, $(e)$ giving the reason; (2) there is an impact of the applying of PBLM with animation toward the student's result of learning physics that includes the result of learning in the cognitif area that follows the Bloom's taxonomy, that is C1 till C6 (remembering, knowing, applying, analyzing, evaluating, and creating).
\end{abstract}

Keywords: Problem-Based Learning Model, Animation, Critical Thinking Skill, Result of Learning

\section{PENDAHULUAN}

Ilmu Pengetahuan Alam (IPA) adalah sebuah kumpulan pengetahuan, cara berpikir, dan cara penyelidikan. Salah satu cabang dari IPA adalah fisika. Sebagai sebuah ilmu, Fisika memiliki beberapa konsep yang abstrak, artinya konsep tersebut datang dari imajinasi ilmuan yang hanya dapat dijelaskan secara teoritis (Suseno dalam Rahmatullah, 2017).

Selama proses pembelajaran, guru semestinya membantu siswa untuk aktif dalam mencari konsep, prinsip, dan fakta bagi diri mereka sendiri, bukan hanya memberikan ceramah dan mengendalikan kelas (teacher centered). Dengan demikian, siswa akan mampu untuk membangun pengetahuannya sendiri (Hikmawati, 2015). Proses pembelajaran yang bersifat teacher centered masih terjadi di SMAN 5 Mataram. Hal ini didasarkan pada hasil observasi yang telah di lakukan di SMAN 5 Mataram.
Proses pembelajaran yang masih bersifat teacher centered dapat mengakibatkan siswa menjadi pasif dan kurang memahami materi pembelajaran. Akibatnya, kemampuan berpikir kritis dan hasil belajar fisika siswa menjadi rendah.

Untuk mengatasi hal tersebut diperlukan sebuah model pembelajaran yang tepat. Salah satu model pembelajaran yang dapat digunakan adalah model pembelajaran berbasis masalah (MPBM) berbantuan media animasi. MPBM adalah suatu model pembelajaran yang menggunakan masalah sebagai titik tolak pembelajaran. Masalah tersebut adalah masalah yang memenuhi konteks dunia nyata yang ada dalam buku teks maupun dari peristiwa yang terjadi di lingkungan sekitar (Kuru et al. dalam Herayanti \& Habibi, 2015).

Ahmad et al. (2015) menyatakan bahwa MPBM merupakan model pembelajaran yang menyajikan berbagai 
permasalahan nyata dalam kehidupan sehari-hari siswa. Pembelajaran berbasis masalah terdiri atas serangkaian kegiatan pembelajaran yang dirancang untuk membantu siswa meningkatkan kemampuan berpikir kritisnya. Dalam proses pembelajaran tersebut siswa membangun pemahaman konsep mereka sendiri dengan memodifikasi atau memperluas pengetahuan yang sudah ada (Prastiwi dkk, 2014).

MPBM merupakan suatu pembelajaran yang berpusat pada siswa (student centered), sehingga proses pembelajaran lebih bermakna karena adanya pengalaman nyata dari siswa. Pengalaman nyata inilah yang dapat memberikan kesan bermakna pada siswa, sehingga dapat memberikan peningkatan pada kemampuan berpikir kritis dan hasil belajar siswa (Listiawati dkk, 2015). Pembelajaran dapat dilaksanakan secara offline menggunakan multimedia maupun online melalui $e$ learning. Program multimedia adalah media pembelajaran yang berbasis komputer yang menggabungkan dan mensinergikan semua media yang terdiri dari teks, grafis, foto, video, animasi, musik, narasi, dan interaktivitas yang diprogram berdasarkan teori pembelajaran (Taufik, 2008).

Media animasi yang merupakan bagian dari multimedia tersebut adalah media yang mengandung suara, tulisan dan gambar yang dapat bergerak. Media animasi ini sering digunakan dalam model simulasi berbasis komputer (Gunawan, 2015). MPBM berbantuan media animasi merupakan modifikasi terhadap MPBM dengan menambahkan media animasi dalam proses pembelajarannya.

Berpikir kritis merupakan kemampuan berpikir yang terdiri atas kemampuan menganalisis, mensintesis, dan mengevaluasi (Gokhale, 1995). Berpikir kritis adalah cara berpikir yang mengandung pertanyaan, percobaan, dan keyakinan terhadap pengetahuan yang telah diperoleh melalui percobaan tersebut. Di dalam proses berpikir kritis, seseorang mendukung pendapatnya dengan menyediakan bukti tentang persoalan yang didiskusikan dengan cara tertentu sehingga dapat meyakinkan bahwa pendapatnya adalah benar (Judge et al., 2009). Hasil belajar adalah kemampuan yang dimiliki siswa setelah melaksanakan pembelajaran (Mutmainnah dkk, 2017). Sementara itu menurut Gunada dkk (2015) hasil belajar adalah perubahan kemampuan yang diperoleh setelah pelaksanaan kegiatan pembelajaran. Perubahan kemampuan yang dialami mencakup aspek kognitif, afektif, dan psikomotorik.

\section{METODE PENELITIAN}

Jenis penelitian ini adalah eksperimen semu. Penelitian eksperimen semu adalah suatu cara untuk menguji sebab-akibat, di mana diberikan perlakuan kepada subjek tertentu untuk dicari tahu pengaruhnya. Desain penelitian dalam penelitian ini adalah nonequivalent control group design. Desainnya seperti Tabel 1 (Setyosari, 2010).

Tabel 1. Desain penelitian

\begin{tabular}{lccc}
\hline Kelas & $\begin{array}{c}\text { Tes } \\
\text { awal }\end{array}$ & Perlakuan & $\begin{array}{c}\text { Tes } \\
\text { akhir }\end{array}$ \\
\hline Eksperimen & $\mathrm{O}_{1}$ & $\mathrm{X}_{1}$ & $\mathrm{O}_{2}$ \\
Kontrol & $\mathrm{O}_{3}$ & $\mathrm{X}_{2}$ & $\mathrm{O}_{4}$ \\
\hline
\end{tabular}

Variabel dalam penelitian ini terdiri atas: variabel bebas berupa MPBM berbantuan media animasi dan model pembelajaran langsung; variabel terikat berupa kemampuan berpikir kritis dan hasil belajar fisika siswa; dan variabel kontrol berupa pengetahuan awal kelas eksperimen dan kelas kontrol yang diperoleh melalui hasil tes awal, guru, materi, tujuan pembelajaran, instrumen yang digunakan, dan cara penilaian. Penelitian dilakukan dalam 3 tahap, yaitu tahap perencanaan, pelaksanaan, dan penyelesaian. Sebelum pemberian perlakuan siswa pada kedua kelas sampel diberikan tes awal untuk mengetahui 
kemampuan awal yang dimilikinya. Setelah diberikan perlakuan, siswa diberikan tes akhir untuk mengetahui pengaruh perlakuan yang telah diberikan tersebut.

Penelitian ini dilaksanakan di SMAN 5 Mataram pada tahun ajaran 2016/2017. Populasi penelitian adalah semua siswa kelas XI MIPA. Sampelnya adalah kelas XI MIPA 4 sebagai kelas eksperimen dan kelas XI MIPA 6 sebagai kelas kontrol. Pengumpulan data menggunakan teknik tes berupa tes pilihan ganda sebanyak 20 soal untuk mengukur hasil belajar fisika siswa, dan tes isian sebanyak 5 soal untuk mengukur kemampuan berpikir kritis siswa.

Instrumen tes pilihan ganda telah diuji dengan uji validitas butir soal, uji reliabilitas, uji tingkat kesukaran soal, dan uji daya beda soal. Uji validitas menggunakan rumus korelasi product moment dengan angka kasar. Reliabilitas soal diukur menggunakan rumus KR-20. Tingkat kesukaran soal dianalisis menggunakan indeks kesukaran. Daya beda soal ditentukan dengan menghitung selisih proporsi jawaban benar antara dua kelompok siswa. Tes isian diuji dengan validasi ahli.

Prasyarat analisis data berupa uji homogenitas menggunakan uji $\mathrm{F}$ dan uji normalitas menggunakan uji Chi Kuadrat. Uji homogenitas dilakukan untuk memperoleh asumsi bahwa kedua kelas sampel memiliki kondisi awal yang sama. Uji normalitas dilakukan untuk mengetahui penyebaran data hasil tes dari kedua kelas sampel. Analisis uji hipotesis dilakukan menggunakan uji $\mathrm{t}^{\prime}$. Uji hipotesis dilakukan untuk mengetahui perbedaan kemampuan berpikir kritis dan hasil belajar fisika siswa pada kedua kelas setelah diberi perlakuan.

\section{HASIL DAN PEMBAHASAN}

Pengambilan data kemampuan awal dan akhir dilakukan dengan memberikan tes, yaitu tes awal dan tes akhir. Tes awal diberikan sebelum kedua kelas sampel diberikan perlakuan, sedangkan tes akhir diberikan setelah kedua kelas sampel diberikan perlakuan. Perlakuan yang diberikan berupa penggunaan MPBM berbantuan media animasi pada kelas eksperimen, dan penggunaan model pembelajaran langsung pada kelas kontrol.

Sebelum melakukan uji hipotesis pada hasil tes akhir kemampuan berpikir kritis dan hasil belajar fisika siswa, dilakukan terlebih dahulu uji normalitas dan uji homogenitas. Uji homogenitas data dilakukan terhadap data hasil tes awal dan tes akhir. Hal ini dilakukan dengan alasan bahwa uji homogenitas perlu dilakukan terhadap data hasil tes awal untuk mengetahui varian data dari kedua kelas sampel sebelum diberikan perlakuan.

Data tes awal yang homogen menunjukkan bahwa kedua kelas sampel memiliki siswa dengan pengetahuan awal yang setara. Dengan kata lain, siswa-siswa pada kedua kelas sampel tersebut dapat dijadikan sampel untuk mewakili populasi dalam sebuah penelitian. Sebaliknya, apabila varian data hasil tes awal kedua kelas tersebut heterogen, maka siswa-siswa pada kelas tersebut memiliki pengetahuan awal yang berbeda. Dengan demikian, kedua kelas tersebut tidak dapat dijadikan sebagai sampel dalam penelitian. Selain itu, pengetahuan awal yang berbeda ini dapat mempengaruhi efektivitas pemberian perlakuan yang diberikan selama penelitian berlangsung.

Pengujian homogenitas data tes akhir dilakukan untuk dapat menentukan jenis uji hipotesis yang digunakan. Apabila hasil uji homogenitas data tes akhir menunjukkan varian yang homogen, maka analisis uji hipotesis yang dapat digunakan adalah uji-t. Namun, apabila hasil uji homogenitas data tes akhir adalah heterogen, maka analisis uji hipotesis yang dapat digunakan adalah uji-t'

Sementara itu, uji normalitas hanya dilakukan pada data hasil tes akhir. Hal ini 
didasarkan pada tujuan dilakukannya uji normalitas, yaitu sebagai prasyarat untuk menentukan jenis uji hipotesis yang digunakan. Dengan kata lain, pengujian normalitas data pada hasil tes awal tidak diperlukan. Hasil uji normalitas data sangatlah diperlukan dalam proses lanjutan pada uji hipotesis penelitian. Apabila uji normalitas menunjukkan bahwa data memiliki sebaran yang tidak normal, maka uji parametrik tidak dapat digunakan untuk menguji hipotesis penelitian, melainkan uji non-parametrik yang dapat digunakan untuk menguji hipotesisnya. Begitu juga sebaliknya.

\section{Kemampuan Berpikir Kritis Siswa}

Hasil penelitian ini menunjukkan bahwa kemampuan akhir berpikir kritis siswa berbeda dengan kemampuan awal berpikir kritisnya. Kemampuan berpikir kritis siswa kelas eksperimen maupun kelas kontrol mengalami perubahan yang positif. Perbedaan hasil kemampuan berpikir kritis tersebut disebabkan oleh perbedaan model pembelajaran yang digunakan selama proses pembelajaran pada kedua kelas sampel.

Berdasarkan analisis hasil tes awal, diperoleh nilai rata-rata kemampuan berpikir kritis siswa kelas eksperimen adalah 39,08 dan nilai rata-rata kemampuan berpikir kritis siswa kelas kontrol adalah 27,37. Sementara itu, hasil analisis tes akhir kemampuan berpikir kritis siswa menunjukkan nilai ratarata siswa pada kelas eksperimen adalah 65,28 dan nilai rata-rata siswa pada kelas kontrol adalah 51,29. Perbandingan nilai rata-rata hasil tes awal dan tes akhir kemampuan berpikir kritis siswa pada kelas eksperimen dan kelas kontrol ditunjukkan pada Gambar 1.

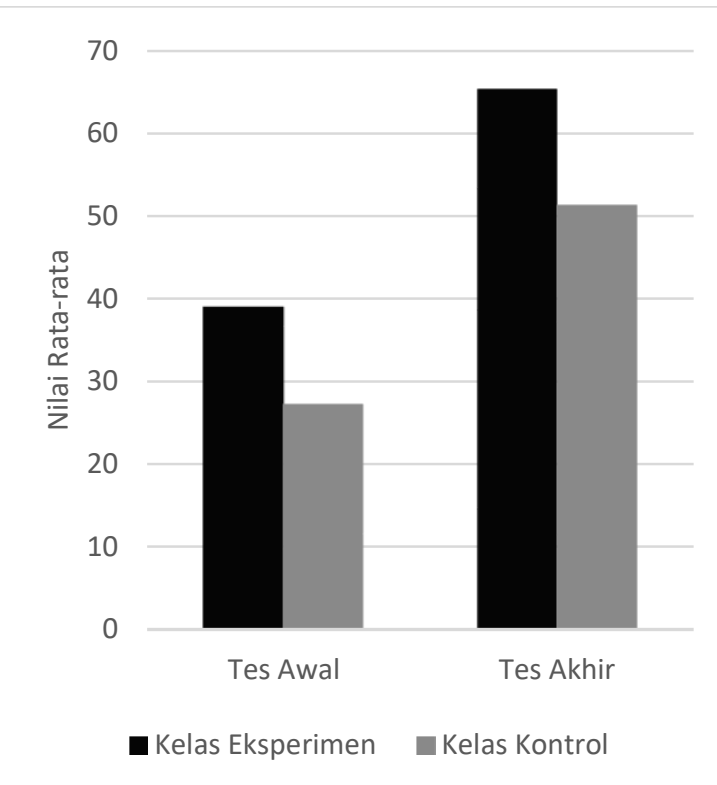

Gambar 1. Grafik Perbandingan Nilai Ratarata Tes Kemampuan Berpikir Kritis Siswa

Dalam penelitian ini, data tes awal kemampuan berpikir kritis siswa dari kelas eksperimen dan kelas kontrol memiliki varian yang homogen. Oleh karena itu, penelitian pada kedua kelas sampel tersebut dapat dilakukan. Sedangkan data hasil tes akhir kemampuan berpikir kritis siswa dari kedua kelas sampel memiliki varian yang heterogen. Oleh karena itu, uji- $\mathrm{t}^{\prime}$ digunakan untuk menguji hipotesis penelitian. Hasil uji homogenitas data tes awal dan tes akhir kemampuan berpikir kritis siswa dapat dilihat pada Tabel 2.

Tabel 2. Hasil Uji Homogenitas Tes Kemampuan Berpikir Kritis Siswa

\begin{tabular}{llccccc}
\hline & Kelas & Jumlah Peserta Didik & Varian & $\mathbf{F}_{\text {hitung }}$ & $\mathbf{F}_{\text {tabel }}$ & Kesimpulan \\
\hline \multirow{2}{*}{ Tes Awal } & Eksperimen & 38 & 95,75 & 1,48 & \multirow{2}{*}{1,73} & \multirow{2}{*}{ Homogen } \\
& Kontrol & 38 & 64,51 & & & \\
\multirow{2}{*}{ Tes Akhir } & Eksperimen & 36 & 329,92 & \multirow{2}{*}{6,35} & 1,77 & \multirow{2}{*}{ Heterogen } \\
& Kontrol & 35 & 51,98 & & & \\
\hline
\end{tabular}

Sementara itu, hasil uji normalitas data tes akhir kemampuan berpikir kritis siswa adalah datanya terdistribusi secara normal. Oleh karena itu, uji parametrik dapat digunakan dalam uji hipotesis. Dengan mempertimbangkan hasil uji 
homogenitas dan normalitas data tes akhir kemampuan berpikir kritis siswa, maka uji hipotesis terhadap variabel kemampuan berpikir kritis siswa yang digunakan dalam penelitian ini adalah uji-t'. Hasil uji normalitas tes akhir kemampuan berpikir kritis siswa dapat dilihat pada Tabel 3.

Tabel 3. Hasil Uji Normalitas Tes Akhir Kemampuan Berpikir Kritis Siswa

\begin{tabular}{lccc}
\hline \multicolumn{1}{c}{ Kelas } & $\boldsymbol{\chi}^{\mathbf{2}}{ }_{\text {hitung }}$ & $\boldsymbol{\chi}_{\text {tabel }}{ }_{\text {r }}$ & Kesimpulan \\
\hline Eksperimen & 5,67 & 11,07 & Data terdistribusi normal \\
Kontrol & 6,73 & 9,49 & Data terdistribusi normal \\
\hline
\end{tabular}

Hasil tes awal menunjukkan bahwa kemampuan awal berpikir kritis siswa pada kelas eksperimen maupun kelas kontrol masih tergolong dalam kategori kurang kritis. Hal ini terlihat dari nilai rata-rata tes awal kemampuan berpikir kritis siswa masing-masing kelas, yaitu untuk kelas eksperimen sebesar 39,08 dan untuk kelas kontrol sebesar 27,37. Hal ini disebabkan karena kurang dilatihnya siswa untuk berpikir kritis melalui model pembelajaran yang sesuai untuk meningkatkan kemampuan berpikir kritis mereka.

Berdasarkan hasil pengamatan selama proses pembelajaran berlangsung, terlihat bahwa perlakuan yang diberikan pada kelas ekperimen membuat siswa lebih aktif dalam belajar dan meningkatkan pemahaman konsep fisika siswa. Hal ini dikarenakan bahwa pada MPBM siswa diarahkan dan dibimbing untuk lebih aktif menemukan konsep fisika dari peristiwa yang terjadi di dalam kehidupan sehari-harinya. Siswa merasa bahwa mereka membutuhkan materi yang dijelaskan untuk menjawab rasa keingintahuan mereka sehingga mereka belajar dengan kesadaran penuh. Sedangkan pada media animasi berbasis PhET (Physics Education Technology), terdapat simulasi yang bersifat teori dan percobaan sehingga siswa dapat memanipulasi kegiatan yang berhubungan dengan eksperimen (Finkelstein, 2006).

Media animasi berbasis PhET merupakan media yang dapat mendukung MPBM itu sendiri dalam menyampaikan konsep-konsep materi usaha dan energi. Melalui program PhET, siswa tidak hanya mendengar tetapi juga melihat secara langsung tentang apa yang sedang dipelajari, misalnya pada materi usaha dan energi, bisa dilihat bagaimana arah hubungan antara energi kinetik, energi potensial dan energi mekanik. Dengan begitu siswa menjadi lebih mudah mengingat dan memahami materi yang mereka pelajari.

Media visual adalah media yang berperan sangat penting dalam proses pembelajaran. Media jenis ini berkaitan dengan indra penglihatan. Media visual dapat memperlancar pemahaman (misalnya melalui elaborasi struktur dan organisasi) dan memperkuat ingatan. Visual dapat pula menumbuhkan minat siswa dan dapat memberikan hubungan antara isi materi pelajaran dengan dunia nyata. Agar menjadi efektif, visual sebaiknya ditempatkan pada konteks yang bermakna dan siswa harus berinteraksi dengan visual (image) itu untuk meyakinkan adanya proses informasi (Musfiqon, 2012). Media animasi merupakan salah satu bentuk dari media visual itu sendiri. Media animasi yang digunakan dalam penelitian ini adalah media animasi yang berbasis adobe flash player dan program PhET.

Penggunaan media animasi ini diterapkan pade fase ketiga dari sintaks MPBM yaitu, membimbing penyelidikan individu dan kelompok. Penerapan media animasi pada fase ketiga ini sangat cocok dilakukan karena pada fase ini siswa 
melakukan penyelidikan atau percobaan guna mencari jawaban dari permasalahan yang diberikan. Penggunaan MPBM berbantuan media animasi ini akhirnya merangsang rasa ingin tahu siswa yang kemudian dilanjutkan dengan melakukan suatu percobaan untuk membuktikan apa yang telah dipelajari, sehingga siswa menjadi mengerti dan mengetahui serta menerima teori yang telah dipelajari.

Pemanfaatan media animasi dalam proses pembelajaran dapat meningkatkan kemampuan berpikir kritis siswa telah terbukti berhasil diterapkan. Fakta ini didukung oleh penelitian sebelumnya yang menyatakan bahwa penggunaan MPBM berbantuan simulasi komputer memberikan dampak yang positif terhadap kemampuan berpikir kritis mahasiswa (Herayanti dan Habibi, 2015). Selain itu, penelitian yang telah dilakukan oleh Wulan dkk (2013) juga menyatakan bahwa penggunaan MPBM mampu meningkatkan kemampuan siswa dalam menyelesaikan soal-soal yang berbentuk cerita. Penelitian lainnya juga telah dilakukan oleh Santoso dkk (2016) yang menyatakan bahwa penggunaan MPBM berbantuan media komputer memberikan pengaruh yang positif terhadap kemampuan berpikir kritis siswa.

Hasil uji hipotesis penelitian yang telah dilakukan terhadap variabel kemampuan berpikir kritis siswa menunjukan bahwa: $\mathrm{t}_{\text {hitung }}^{\prime}=4,29$ dan $\mathrm{t}_{\text {alpha }}=2.03$. Karena $\quad \mathrm{t}_{\text {hitung }}^{\prime}>\mathrm{t}_{\text {alpha }}$ (4,29 > 2,03), maka $\mathrm{H}_{01}$ ditolak dan $\mathrm{H}_{\mathrm{a} 1}$ diterima. Dengan demikian dapat disimpulkan bahwa terdapat pengaruh MPBM berbantuan media animasi terhadap kemampuan berpikir kritis siswa berupa peningkatan kemampuan dalam hal: (a) memfokuskan pertanyaan, (b) menganalisis argumen atau mengidentifikasi alasan, (c) menginduksi dan mempertimbangkan hasil induksi, (d) mengevaluasi/menilai hasil pertimbangan, (e) memberikan alasan.

\section{Hasil Belajar Fisika Siswa}

Hasil penelitian juga menunjukkan bahwa hasil tes akhir hasil belajar fisika siswa berbeda dengan hasil tes awalnya. Perbedaan hasil tes ini disebabkan oleh perbedaan perlakuan yang diberikan pada kedua kelas sampel. Berdasarkan analisis hasil tes awal diperoleh nilai rata-rata hasil belajar fisika siswa pada kelas eksperimen adalah 61,58 dan 43,42 pada kelas kontrol. Sedangkan pada tes akhir diperoleh nilai rata-rata hasil belajar fisika siswa pada kelas eksperimen adalah 80,97 dan nilai rata-rata hasil belajar fisika siswa pada kelas kontrol adalah 72,00. Perbandingan nilai rata-rata hasil tes awal dan tes akhir hasil belajar fisika siswa pada kelas eksperimen dan kelas kontrol ditunjukkan pada Gambar 2 berikut.

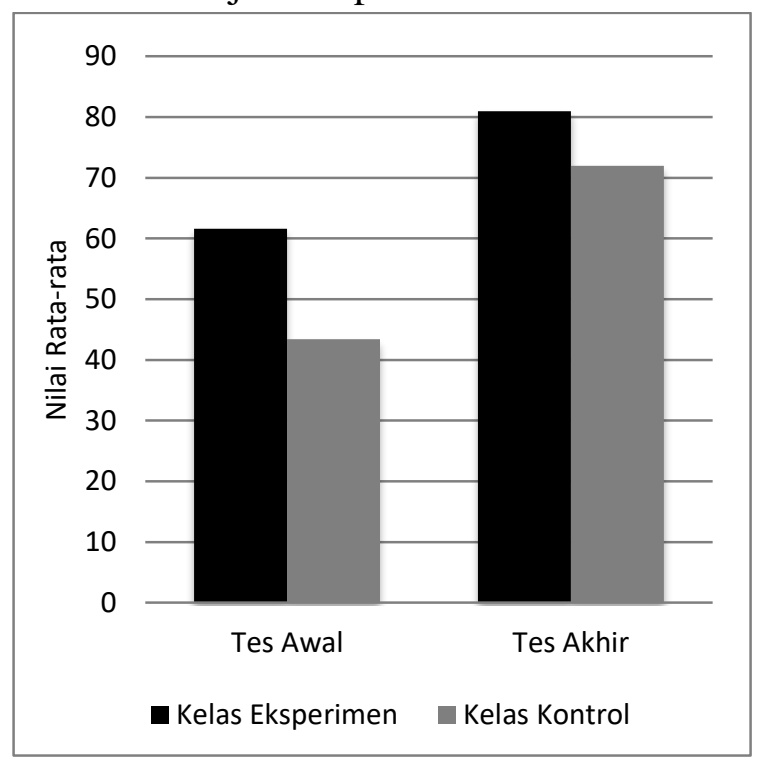

Gambar 2. Perbandingan Nilai Rata-rata Tes Hasil Belajar Fisika Siswa

Berdasarkan analisis data tes awal hasil belajar fisika siswa diperoleh nilai varian dari kedua kelas sampel adalah homogen. Oleh karena itu, penelitian pada kedua kelas sampel tersebut dapat dilanjutkan. Sedangkan data hasil tes akhir hasil belajar fisika siswa dari kedua kelas sampel memiliki varian yang heterogen. Oleh karena itu, untuk menguji hipotesis 
penelitian digunakan uji-t'. Hasil uji homogenitas tes awal dan tes akhir hasil belajar fisika siswa disajikan pada Tabel 4 .

Sementara itu, hasil uji normalitas data tes akhir hasil belajar fisika siswa adalah datanya terdistribusi secara normal. Oleh karena itu, uji parametrik dapat digunakan dalam pengujian hipotesis. Dengan mempertimbangkan hasil uji homogenitas dan normalitas data tes akhir, maka uji hipotesis terhadap variabel hasil belajar fisika siswa yang digunakan dalam penelitian ini adalah uji-t'. Hasil uji normalitas tes akhir hasil belajar fisika siswa dapat dilihat pada Tabel 5 .

Tabel 4. Hasil Uji Homogenitas Tes Hasil Belajar Fisika Siswa

\begin{tabular}{lcccccc}
\hline & Kelas & $\begin{array}{c}\text { Jumlah Peserta } \\
\text { Didik }\end{array}$ & Varian & $\mathbf{F}_{\text {hitung }}$ & $\mathbf{F}_{\text {tabel }}$ & Kesimpulan \\
\hline \multirow{2}{*}{ Tes Awal } & Eksperimen & 38 & 43,38 & \multirow{2}{*}{1,23} & \multirow{2}{*}{1,74} & Homogen \\
& Kontrol & 38 & 35,28 & & & \\
\multirow{2}{*}{ Tes Akhir } & Eksperimen & 36 & 89,74 & 2,24 & 1,77 & Heterogen \\
& Kontrol & 35 & 40 & & & \\
\hline
\end{tabular}

Tabel 5. Hasil Uji Normalitas Tes Akhir Hasil Belajar Fisika Siswa

\begin{tabular}{cccc}
\hline Kelas & $\boldsymbol{\chi}^{\mathbf{2}}{ }_{\text {hitung }}$ & $\boldsymbol{\chi}^{\mathbf{2}}{ }_{\text {tabel }}$ & Kesimpulan \\
\hline Eksperimen & 4,22 & 12,59 & Data terdistribusi normal \\
Kontrol & 5,58 & 11,07 & Data terdistribusi normal \\
\hline
\end{tabular}

Tes awal terhadap hasil belajar fisika siswa menunjukkan bahwa kemampuan awal hasil belajar fisika siswa pada kelas eksperimen dan kelas kontrol masih berada di bawah nilai kriteria kelulusan minimal (KKM). Hal ini terlihat dari nilai rata-rata tes awal hasil belajar fisika siswa masingmasing kelas, yaitu untuk kelas eksperimen 61,58 dan untuk kelas kontrol sebesar 43,42. Hal ini disebabkan oleh kurang tepatnya model pembelajaran yang digunakan selama proses pembelajaran berlangsung. Model pembelajaran yang tepat harus digunakan selama proses pembelajaran agar dapat meningkatkan hasil belajar fisika siswa. Salah satu alternatif untuk mencapai hal tersebut, yaitu dengan melaksanakan pembelajaran menggunakan MPBM berbantuan media animasi.

Hasil belajar merupakan hal yang dapat dipandang dari dua sisi yaitu sisi siswa dan dari sisi guru. Dari sisi siswa, hasil belajar merupakan tingkat perkembangan mental yang lebih baik bila dibandingkan pada saat sebelum belajar. Tingkat perkembangan mental tersebut terwujud pada jenis-jenis ranah kognitif, afektif, dan psikomotor. Sedangkan dari sisi guru, hasil belajar merupakan saat terselesaikannya bahan pelajaran.

Hasil belajar bukan hanya sekedar angka yang dihadiahkan oleh guru untuk siswa atas kegiatan belajarnya. Hasil belajar sering kali digunakan sebagai ukuran untuk mengetahui seberapa jauh seseorang menguasai bahan yang sudah diajarkan. Untuk mengaktualisasikan hasil belajar tersebut diperlukan serangkaian pengukuran menggunakan alat evaluasi yang baik dan memenuhi syarat. Oleh karenanya, hasil belajar dapat berupa perubahan dalam kemampuan kognitif, afektif, dan psikomotor, tergantung dari tujuan pengajaran.

Hasil belajar merupakan perubahan tingkat laku siswa dalam bentuk perubahan pengetahuan dan pemahaman serta keterampilan dan sikapnya setelah menjalani 
suatu proses pembelajaran dan interaksi sosial dengan orang lain. Sementara itu, hasil belajar fisika yang dimaksud dalam penelitian ini adalah perubahan pengetahuan siswa dalam mata pelajaran fisika. Di mana hasil belajar tersebut merupakan perubahan pengetahuan siswa dalam ranah kognitif mulai dari C1 sampai dengan C6 yang terdiri atas: mengingat, memahami, menerapkan, menganalisis, mengevaluasi, dan mencipta. Kemampuan ranah kognitif ini sesuai dengan taksonomi Bloom.

$$
\text { Proses pembelajaran yang }
$$

menggunakan MPBM berbantuan media animasi memberikan pengaruh positif terhadap hasil belajar fisika siswa. Fakta ini diperkuat oleh beberapa penelitian sebelumnya, di antaranya adalah penelitian yang dilakukan oleh Listiawati dkk (2015) yang menyatakan bahwa MPBM berbantuan simulasi interaktif memberikan pengaruh yang positif terhadap hasil belajar fisika siswa. Selain itu, Sudria (2011) dalam penelitiannya juga menemukan bahwa penggunaan media komputer dalam proses pembelajaran mampu menyajikan konsep yang abstrak menjadi lebih konkrit dan lebih menarik, sehingga mampu meningkatkan hasil belajar siswa.

Retna (2014) dalam penelitiannya juga menemukan bahwa penggunaan media berbasis PhET terbukti dapat meningkatkan hasil belajar siswa. Hal ini disebabkan karena siswa lebih aktif dan antusias dalam belajar dibandingkan dengan kelas kontrol yang belajar menggunakan model pembelajaran langsung. Program komputer yang berbasis PhET juga memberikan kesan yang positif, menarik, menghibur dan membantu menjelaskan secara mendalam tentang suatu fenomena alam (Taufik, 2008).

Setelah dilakukan uji hipotesis dengan menggunakan uji statistik yang menggunakan uji- $\mathrm{t}^{\prime}$, diperoleh nilai $\mathrm{t}^{\prime}{ }_{\text {hitung }}$ lebih besar dari $t_{\text {alpha dengan nilai }}$ $\mathrm{t}_{\text {hitung }}^{\prime}=4,71 ; \mathrm{t}_{\text {alpha }}=2,03 . \quad$ Karena $\mathrm{t}^{\prime}{ }_{\text {hitung }}>\mathrm{t}_{\text {alpha }}$ yaitu 4,71 $>2,03$, maka $\mathrm{H}_{02}$ ditolak dan $\mathrm{H}_{\mathrm{a} 2}$ diterima. Dengan demikian dapat disimpulkan bahwa terdapat pengaruh model pembelajaran berbasis masalah berbantuan media animasi terhadap hasil belajar fisika siswa berupa peningkatan hasil belajar fisika siswa dalam ranah kognitif menurut taksonomi Bloom, yaitu dari C1 sampai C6 (mengingat, memahami, menerapkan, menganalisis, mengevaluasi, dan mencipta).

\section{PENUTUP}

Berdasarkan hasil penelitian dan pembahasan dapat disimpulkan bahwa terdapat pengaruh MPBM berbantuan media animasi terhadap kemampuan berpikir kritis siswa berupa peningkatan kemampuan dalam hal: (a) memfokuskan pertanyaan, (b) menganalisis argumen/mengidentifikasi alasan, (c) menginduksi dan mempertimbangkan hasil induksi, (d) mengevaluasi/menilai hasil pertimbangan, (e) memberikan alasan. Selain itu, MPBM berbantuan media animasi juga memiliki pengaruh terhadap hasil belajar fisika siswa berupa peningkatan hasil belajar fisika siswa dalam ranah kognitif menurut taksonomi Bloom, yaitu dari C1 sampai C6 (mengingat, memahami, menerapkan, menganalisis, mengevaluasi, dan mencipta).

Saran-saran yang dapat diberikan yaitu: (1) Penggunaan MPBM sebaiknya digunakan selama proses pembelajaran agar siswa dapat memiliki kemampuan berpikir kritis dan hasil belajar fisika yang lebih baik, (2) Bantuan media animasi sebaiknya digunakan selama proses pembelajaran agar siswa dapat lebih mudah memahami materi yang diberikan, (3) LKS yang digunakan sebaiknya menggunakan kata yang efektif agar siswa mudah memahami maksudnya, (4) Instrumen soal yang digunakan sebaiknya menggunakan kalimat yang 
efektif dan efisian agar siswa mudah memahaminya.

\section{REFERENSI}

Ahmad F., Sukarmin, dan Aminah, N. S. 2015. Pengaruh Pembelajaran Fisika pada Materi Fluida Dinamik Menggunakan Metode Problem Based Learning (PBL) dan Inkuiri Terbimbing Ditinjau dari Kemampuan Awal dan Sikap Ilmiah terhadap Prestasi Belajar dan Kreativitas. Jurnal Inkuiri. 4 (2): 76-86.

Finkelstein, N. 2006. High-Tech Tools for Teaching Physics: the Physics education Technology Project. Merlot Journal of Online Learning and Teaching. 2 (3): 110-120.

Gokhale, A. A. 1995. Collaborative Learning Enhances Critical Thinking. Journal of Technology Education. 7 (1): 22-30.

Gunada, I. W., Sahidu, H., dan Sutrio. 2015. Pengembangan Perangkat Pembelajaran Fisika Berbasis Masalah untuk Meningkatkan Hasil Belajar dan Sikap Ilmiah Mahasiswa. Jurnal Pendidikan Fisika dan Teknologi. 1 (1): 38-46.

Gunawan. 2015. Model Pembelajaran Sains Berbasis ICT. Mataram: FKIP PRESS Universitas Mataram.

Herayanti, L., dan Habibi. 2015. Model Pembelajaran Berbasis Masalah Berbantuan Simulasi Komputer untuk Meningkatkan Keterampilan Berpikir Kritis Calon Guru Fisika. Jurnal Pendidikan Fisika dan Teknologi. 1 (1): 61-66.

Hikmawati. 2015. Pembelajaran Fisika dengan Model Siklus Belajar 5 -E (Engage, Explore, Explain, Elaborate, Evaluate) Sebagai Upaya Meningkatkan Kecakapan Hidup Siswa. Jurnal Pendidikan Fisika dan Teknologi. 1 (1): 27.

Judge, B., Jones, P., and McCreery, E. 2009. Critical Thinking Skills for
Educational Students. United Kingdom: Learning Matters Ltd.

Listiawati, W., Gunawan, dan Sutrio. 2015. Pengaruh Penerapan Model Pembelajaran Berbasis Masalah Berbantuan Simulasi Interaktif Terhadap Hasil Belajar Fisika Siswa. Jurnal Pendidikan Fisika dan Teknologi. 1 (1): 83.

Musfiqon. 2012. Pengembangan Media dan Sumber Pembelajaran. Jakarta: Prestasi Pustaka Publisher.

Mutmainnah, Rokhmat, J., dan 'Ardhuha, J. 2017. Pengaruh Penerapan Metode Pembelajaran Fisika Berbasis Eksperimen Virtual terhadap Motivasi dan Hasil Belajar Fisika Siswa Kelas $\mathrm{X}$ MAN 2 Mataram Tahun Ajaran 2014/2015. Jurnal Pendidikan Fisika dan Teknologi. 1 (3): 41-47.

Prastiwi, I., Soedjoko, E., dan Mulyono. 2014. Efektivitas Pembelajaran Conceptual Understanding Procedures untuk Meningkatkan Kemampuan Siswa pada Aspek Koneksi Matematika. Jurnal Krean. 5 (1): 42.

Rahmatullah, Sahidu, H., dan Ayub, S. 2017. Pengaruh Model Pembelajaran Kooperatif Tipe Group Investigation (GI) dengan Teknik Open-Ended Problem terhadap Aktivitas dan Hasil Belajar Fisika Siswa SMAN 3 Mataram. Jurnal Pendidikan Fisika dan Teknologi. 3 (2): 109-118.

Retna, W. 2014. Penerapan Pembelajaran Fisika dengan Media Simulasi PhET pada Pokok Bahasan Gaya untuk Meningkatkan Hasil Belajar Siswa Kelas VIIIA SMPN 6 Yogyakarta. Jurnal Prosiding Pertemuan Ilmiah XXVIII HFI Jateng \& DIY: 400-402.

Santoso, R., Darmadi I. W., dan Darsikin. 2016. Pengaruh Model Pembelajaran Berbasis Masalah Berbantuan Media Komputer terhadap Kemampuan Berpikir Kritis Siswa SMA Negeri 5 Palu. Jurnal Pendidikan Fisika Tadulako. 4 (1): 39-40. 
Setyosari, P. 2010. Metode Penelitian Pendidikan dan Pengembangan. Jakarta: Kencana Prenada Media Group.

Sudria, I. B. N., Redhana, I. W., dan Samiasih L. 2011. Pengaruh Pembelajaran Interaktif Laju Reaksi Berbantuan Komputer terhadap Hasil Belajar Siswa. Jurnal Pendidikan dan Pengajaran. 44 (1-3): 25-33.

Taufik, M. 2008. Pembuatan Media Pembelajaran Berbasis Compact Disc untuk Menampilkan Simulasi dan Virtual Labs Besaran-Besaran Fisika. Jurnal Pijar MIPA. 3 (1): 23.

Wulan, B. R. S., Effendi, D., dan Widayati, S. A. 2013. Pembelajaran Berdasarkan Masalah (Problem Based Instruction) dalam Meningkatkan Kemampuan Siswa Menyelesaikan Soal Cerita. Jurnal Pendidikan Matematika STKIP PGRI Sidoarjo. 1 (1): 25-34. 